\title{
MIBE acts as antagonist ligand of both estrogen receptor $\alpha$ and GPER in breast cancer cells
}

\author{
Rosamaria Lappano', Maria Francesca Santolla', Marco Pupo ${ }^{1}$, Maria Stefania Sinicropi ${ }^{2}$, Anna Caruso², \\ Camillo Rosano ${ }^{3}$ and Marcello Maggiolini ${ }^{*}$
}

\begin{abstract}
Introduction: The multiple biological responses to estrogens are mainly mediated by the classical estrogen receptors $E R \alpha$ and $E R \beta$, which act as ligand-activated transcription factors. ERo exerts a main role in the development of breast cancer; therefore, the ER antagonist tamoxifen has been widely used although its effectiveness is limited by de novo and acquired resistance. Recently, GPR30/GPER, a member of the seventransmembrane $\mathrm{G}$ protein-coupled receptor family, has been implicated in mediating the effects of estrogens in various normal and cancer cells. In particular, GPER triggered gene expression and proliferative responses induced by estrogens and even ER antagonists in hormone-sensitive tumor cells. Likewise, additional ER ligands showed the ability to bind to GPER eliciting promiscuous and, in some cases, opposite actions through the two receptors. We synthesized a novel compound (ethyl 3-[5-(2-ethoxycarbonyl-1-methylvinyloxy)-1-methyl-1H-indol-3-yl]but-2enoate), referred to as MIBE, and investigated its properties elicited through ER $\alpha$ and GPER in breast cancer cells.

Methods: Molecular modeling, binding experiments and functional assays were performed in order to evaluate the biological action exerted by MIBE through ER $\alpha$ and GPER in MCF7 and SkBr3 breast cancer cells.

Results: MIBE displayed the ability to act as an antagonist ligand for ER $\alpha$ and GPER as it elicited inhibitory effects on gene transcription and growth effects by binding to both receptors in breast cancer cells. Moreover, GPER was required for epidermal growth factor receptor (EGFR) and ERK activation by EGF as ascertained by using MIBE and performing gene silencing experiments.

Conclusions: Our findings provide novel insights on the functional cross-talk between GPER and EGFR signaling. Furthermore, the exclusive antagonistic activity exerted by MIBE on ER $\alpha$ and GPER could represent an innovative pharmacological approach targeting breast carcinomas which express one or both receptors at the beginning and/ or during tumor progression. Hence, the simultaneous inhibition of both ER $\alpha$ and GPER may guarantee major therapeutic benefits in respect to the use of a selective estrogen receptor antagonist.
\end{abstract}

\section{Introduction}

Estrogens regulate many aspects of human physiology and influence diverse pathological processes, including the development of hormone-dependent tumors [1]. The biological actions of estrogens are mainly mediated by the estrogen receptor (ER) $\alpha$ and ER $\beta$, which belong to the nuclear receptor superfamily [1]. Acting as ligand-activated transcription factors, ERs regulate gene expression by binding to responsive elements (ERE) located within the promoter region of estrogen target

\footnotetext{
* Correspondence: marcellomaggiolini@yahoo.it

'Dipartimento Farmaco-Biologico, Università della Calabria, via Bucci, 87036 Rende, Italy

Full list of author information is available at the end of the article
}

genes [1]. In addition, gene regulation can occur in response to estrogens through plasma membrane receptors, such as growth factor receptors or G proteincoupled receptors, and by protein kinase signaling cascades [2].

Prolonged exposure to estrogens represents a major risk factor for the progression of breast cancer [3], which expresses elevated levels of ER $\alpha$ in approximately $70 \%$ of cases [4]. Consequently, ER $\alpha$ antagonists like tamoxifen and raloxifene are currently used as frontline pharmacological interventions in ER $\alpha$-positive breast cancer in order to inhibit the mitogenic stimulation of estrogens [5]. Although there is general concordance between ER $\alpha$ expression and responsiveness to ER-

\section{() Biomed Central}


targeted agents, as indicated by a greater five-year disease-free survival for $E R \alpha$-positive patients receiving tamoxifen, one in four patients does not respond to treatment from the onset and in most patients tamoxifen produces agonist effects after a few years [6].

In order to further characterize the molecular mechanisms involved in the action of estrogens, recent studies have demonstrated that the $G$ protein-coupled receptor, named GPR30/GPER, mediates rapid biological responses to estrogens in diverse normal, as well as transformed, cell types [7]. The potential role of GPER in cancer was supported by numerous investigations performed in different tumor cells, including breast [8-10], endometrial [11], ovarian [12], thyroid [13], prostate [14] and testicular germ cells [15]. In accordance with these findings, GPER has been associated with aggressive features of breast cancer [16], high-grade endometrial tumors [17] and poor prognosis in ovarian cancer [18]. Since its identification to date, the transduction signaling and gene expression profile triggered by GPER have been extensively characterized. The early discovery [8] of a transmembrane receptor able to mediate estrogen responsiveness in ER-negative breast cancer cells was then confirmed by several reports by which GPER was considered as a genuine ER $[10,19]$. Indeed, a whole series of intracellular events, such as the rapid phosphorylation of mitogen-activated protein kinases (MAPK) ERK1/2, the activation of PI3-kinase (PI3K) and phospholipase $\mathrm{C}$ (PLC), the increase in cAMP concentrations and the intracellular calcium mobilization, was shown to follow GPER activation by both estrogens and anti-estrogens [20]. In particular, it was demonstrated that GPER-dependent ERK activation occurs via the transactivation of the epidermal growth factor receptor (EGFR) through matrix metalloproteinase activity and integrin $\alpha 5 \beta 1$, which trigger the extracellular release of heparan-bound epidermal growth factor (HB-EGF) $[8,21]$. Interestingly, a physical and functional cross-talk between GPER and EGFR contributes to the intricate signaling network involved in the stimulation of hormone-sensitive tumors [22,23].

The rapid responses to estrogenic signals mediated by GPER regulate a typical gene signature, as revealed in previous studies, including a microarray analysis $[7,24]$. Of note, GPER target genes were shown to contribute to the proliferation and migration in diverse cancer cell types $[9,11-13,22,24,25]$ as well as in cancer associated fibroblasts (CAFs) [26].

GPER exhibits many of the expected characteristics of an estrogen receptor, including the capability to bind to estrogens, phyto- and xenoestrogens and even the ER antagonists 4-hydroxytamoxifen (OHT) and fulvestrant (ICI 182780$)[10,19,27,28]$. Surprisingly, unlike the antagonistic properties displayed by these anti-estrogens with respect to the classical ERs, both compounds act as GPER agonists $[8,11,19,24]$. Conversely, the well known ER agonist estriol exerts inhibitory effects on GPERmediated signaling [28], confirming the potential opposite functions elicited by estrogenic/anti-estrogenic agents through each type of estrogen receptor. In addition to the selective GPER agonist G-1 [29], GPER ligands showing antagonistic properties have been identified [30,31]. Recently, a GPER antagonist showed at high concentrations limited binding properties and stimulatory activity on ER-mediated transcription [30]. The use of these compounds has greatly advanced our understanding of the role of GPER in numerous biological systems as well as in cancer.

On the basis of the aforementioned findings, GPER may be considered as an additional therapeutic target in estrogen-sensitive tumors, such as breast cancer. In this regard, the opposite functional activity elicited by antiestrogens through the classical ERs and GPER as stated above, could represent a therapeutic concern toward the pharmacological inhibition of all types of estrogen receptor.

We discovered a novel compound, ethyl 3-[5-(2-ethoxycarbonyl-1-methylvinyloxy)-1-methyl-1H-indol-3-yl] but-2-enoate (referred to as MIBE) (Figure 1), which displays the unique property to bind to and inhibit GPER- and ER $\alpha$-mediated signaling in breast cancer cells. The antagonistic action exerted by MIBE on both estrogen receptor types could represent a novel, promising tool for a more comprehensive pharmacological approach to estrogen-dependent tumors such as breast cancer.

\section{Materials and methods}

\section{Molecular modelling and docking simulations}

For docking simulations we used as targets the crystallographic coordinates of ER $\alpha$ in complex with E2 (closed-conformation) as well as with OHT (open conformation) and a GPER molecular model built by homology as described elsewhere (PDB code 1G50; PDB code 3ERT) [28,32,33]. Docking studies were performed by GOLD 5.0.1 (the Cambridge Crystallographic Data Center, UK), a program using a genetic algorithm useful to investigate the full range of ligand conformational flexibility and a partial protein side chain flexibility. As active sites of ER $\alpha$, we identified those atoms that are within $20 \AA$ distance from each atom of the ligand experimental position. Regarding GPER, we identified the $\mathrm{O}$ atom of Phe 208 as the protein active site centre on the basis of our previous docking simulations [28]. In this case, the active site atoms were considered those located within $20 \AA$ from the centre. For each structure, 10 docking solutions were generated allowing an early termination of the 

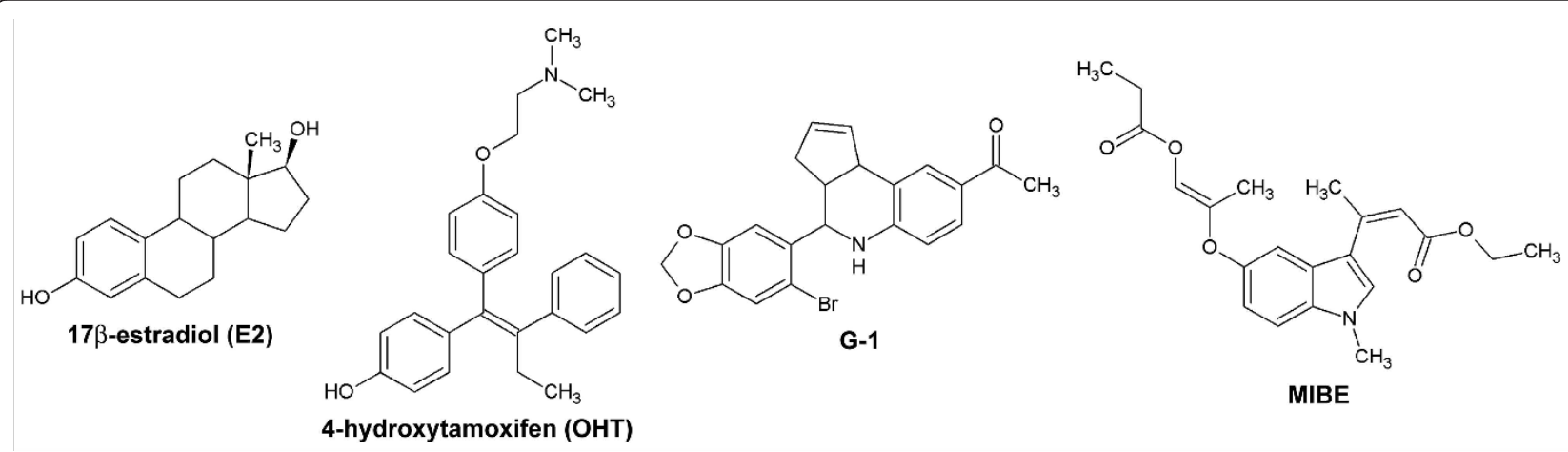

Figure 1 Chemical structures of compounds used. 17beta-estradiol (E2), 4-hydroxytamoxifen (OHT), G-1 and ethyl 3-[5-(2-ethoxycarbonyl-1methylvinyloxy)-1-methyl-1H-indol-3-yl] but-2-enoate (MIBE).

process, if the respective RMSDs of the three highest ranked docking solutions were within $1.5 \AA$ of each other. The default GOLD settings were used for running the simulations. ER $\alpha$ protein side chains Met342, Glu353, Trp383, Met388, Arg394, Phe404, His524 and Leu525 were considered as flexible, while in the GPER model the residues Tyr123, Gln138, Phe206, Phe208, Glu275, Phe278 and His282 were defined flexible side chains allowing their free rotation. The molecular structures of the ligands screened in silico were built and energy minimized with the programs Insight II and Discover3 (Biosym/MSI, San Diego, CA, USA). All the figures were drawn with the program Chimera (UCSF, San Francisco, CA, USA) [34].

\section{Chemistry}

5-Hydroxy-1-methylindole was allowed to react with an excess of ethyl acetoacetate using Indium(III) chloride as a catalyst. The derivative ethyl 3-[5-(2-ethoxycarbonyl-1-methylvinyloxy)-1-methyl-1H-indol-3-yl] but-2-enoate (MIBE) was obtained in good yield $[35,36]$. Melting points were determined on a Kofler melting point apparatus. IR spectra were taken with a Perkin Elmer BX FT-IR (Corporate Headquarters, Waltham, Massachusetts, USA). Mass spectra were taken on a JEOL JMS GCMate spectrometer at ionising potential of $70 \mathrm{eV}(\mathrm{EI}) .{ }^{1} \mathrm{H}-\mathrm{NMR}(400 \mathrm{MHz})$ was recorded on a JEOL Lambda 400 Spectrometer (JEOL Ltd., Tokyo, Japan). Chemical shifts are expressed in parts per million downfield from tetramethylsilane as an internal standard. Thin layer chromatography (TLC) was performed on silica gel 60F-264 (Merck, Frankfurt, Germany). Commercial reagents were purchased from Aldrich Chemical (Milan, Italy), Acros Organics (Carlo Erba Reagenti S.p.A., Rodano, Milan, Italy) and Alfa Aesar (Karlsruhe, Germany). Unless otherwise stated, all commercial reagents were used without further purification.
Procedure for the preparation of MIBE was as follows. Indium (III) chloride (10 mol\%) was added under nitrogen to a mixture of 5-hydroxy-1-methyl-1H-indole and ethyl acetoacetate. The reaction mixture was heated under reflux for two hours, and then it was left to cool to room temperature. Ice water was added and then the reaction mixture was extracted by ethyl acetate. The organic layers were collected and washed with brine, dried over $\mathrm{MgSO}_{4}$ and evaporated under reduced pressure. The solid residue was washed with $\mathrm{Et}_{2} \mathrm{O}$, to give the pure compound MIBE a pink solid, yield of $65 \%, \mathrm{mp}=$ $180^{\circ} \mathrm{C}$; IR (KBr): 3412, 2984, 1705, 1622, 1473, 1373, 1168, 1088, 1027, $805 \mathrm{~cm}^{-1} .{ }^{1} \mathrm{H}-\mathrm{NMR}\left(\mathrm{d}_{6}\right.$-DMSO) $\delta 8.94$ (s, $1 \mathrm{H}, \mathrm{Ar}) ; 7.32\left(\mathrm{~d}, 1 \mathrm{H}, \mathrm{Ar}, \mathrm{J}_{7,6}=8.8 \mathrm{~Hz}\right) ; 6.87(\mathrm{~s}, 1 \mathrm{H}$, Ar); $7.32\left(\mathrm{~d}, 1 \mathrm{H}, \mathrm{Ar}, \mathrm{J}_{6,7}=8.8 \mathrm{~Hz}\right)$; 6.04-6.01 (m, $2 \mathrm{H}, \mathrm{C}=$ $\mathrm{CH})$; 4.11-4.09 (q, 2H, $\left.\mathrm{CH}_{2}\right) ; 3.90-3.88$ (q, $\left.2 \mathrm{H}, \mathrm{CH}_{2}\right) ; 3.76$ $\left(\mathrm{s}, 3 \mathrm{H}, \mathrm{NCH}_{3}\right) ; 1.42\left(\mathrm{~s}, 6 \mathrm{H}, \mathrm{C}-\mathrm{CH}_{3}\right) ; 1.24-1.20(\mathrm{t}, 3 \mathrm{H}$, $\left.\mathrm{CH}_{3}\right)$; 0.95-0.92 (t, 3H, $\left.\mathrm{CH}_{3}\right)$. MS (EI) m/z: $371\left(\mathrm{M}^{+}, 14\right)$.

\section{Reagents}

$17 \beta$-estradiol (E2), 4-hydroxytamoxifen (OHT) and $5 \alpha$ dihydrotestosterone (DHT) were purchased from SigmaAldrich (Milan, Italy). G-1 (1-[4-(-6-bromobenzol [1,3] diodo-5-yl)-3a,4,5,9b-tetrahidro3H5 cyclopenta[c]quinolin-8yl]-ethanone) was bought from Calbiochem (Merck KGaA, Frankfurt, Germany). All compounds were solubilized in ethanol, except G-1 and MIBE which were dissolved in dimethyl sulfoxide (DMSO).

\section{Cell culture}

MCF7 breast cancer cells and human embryonal kidney Hek293 cells were maintained in DMEM with phenol red supplemented with $10 \%$ FBS. SkBr3 breast cancer cells were maintained in RPMI 1640 without phenol red supplemented with $10 \%$ FBS. All cell lines to be processed for immunoblot and RT-PCR assays were switched to medium without serum and phenol red the day before treatments. 
The experiments performed in this study do not require Institute Ethics Board approval, because only commercially available cell lines were used.

\section{Plasmids}

Firefly luciferase reporter plasmids used were ERE-luc for ER $\alpha$ [37], ARE-luc for the Androgen Receptor (AR) [38] and GK1 [37] for the Gal4 fusion proteins Gal-ER $\alpha$ and Gal-ER $\beta$, which were expressed from plasmids GAL93.ER(G) and GAL93.ER $\beta$, respectively, as previously described [37]. The full length AR expression plasmid (AR) was previously described [39]. As the internal transfection control, we co-transfected the plasmid pRL-TK (Promega, Milan, Italy) that expresses Renilla Luciferase. Short hairpin RNA construct against human GPER (shGPR30/shGPER) and the unrelated shRNA control construct were previously described [22].

\section{Transfection, Luciferase assays and gene silencing experiments}

Cells were plated into 24-well plates with $500 \mu \mathrm{l}$ of regular growth medium/well the day before transfection. Cell medium was replaced with medium supplemented with 1\% charcoal-stripped (CS) FBS lacking phenol red and serum on the day of transfection, which was performed using the Fugene 6 Reagent as recommended by the manufacturer (Roche Diagnostics, Milan, Italy) with a mixture containing $0.5 \mu \mathrm{g}$ of reporter plasmid, $2 \mathrm{ng}$ of pRL-TK, $0.1 \mu \mathrm{g}$ of effector plasmid and $0.1 \mu \mathrm{g}$ of full length AR expression plasmid where applicable. After 6 $h$, the medium was replaced again with serum-free medium lacking phenol red and supplemented with $1 \%$ CSFBS, treatments were added at this point and cells were incubated for an additional $18 \mathrm{~h}$. Luciferase activity was then measured using the Dual Luciferase Kit (Promega, Milan, Italy) according to the manufacturer's recommendations. Firefly luciferase activity was normalized to the internal transfection control provided by the Renilla luciferase activity. The normalized relative light unit values obtained from cells treated with vehicle were set as one-fold induction upon which the activity induced by treatments was calculated.

For the gene silencing experiments, cells were plated into 10 -cm dishes, maintained in serum-free medium for $24 \mathrm{~h}$ and then transfected for an additional $48 \mathrm{~h}$ before treatments using Fugene 6 (according to the manufacturer's recommendations) and control vector (shRNA) or shGPER.

\section{Ligand binding assays}

In ligand binding assay for ER $\alpha$, the ability of MIBE to compete with $[3 \mathrm{H}] \mathrm{E} 2$ was evaluated and compared with that of E2. Two picomoles of purified recombinant human ER $\alpha$ protein purchased from PanVera,
Invitrogen S.r.l. (Milan, Italy), each in $20 \mathrm{mM}$ HEPES, $\mathrm{pH}$ 7.4, $1.5 \mathrm{mM}$ EDTA, $0.5 \mathrm{mM}$ dithiothreitol, and 10\% (v/v) glycerol, was incubated with $1 \mathrm{nM}[2,4,6,7-3 \mathrm{H}] \mathrm{E} 2$ (89 Ci/mmol; Ge Healthcare, Milan, Italy) and increasing concentrations of nonlabeled E2 or MIBE for two hours at $37^{\circ} \mathrm{C}$ in a humidified atmosphere of $95 \%$ air $/ 5 \%$ $\mathrm{CO} 2$. Bound and free radioligands were separated on Sephadex G-25 PD-10 columns. The amount of receptor-bound $[3 \mathrm{H}] \mathrm{E} 2$ was determined by liquid scintillation counting.

In ligand binding assay for GPER, SkBr3 cells were grown in $10-\mathrm{cm}$ cell culture dishes, washed two times and incubated with $1 \mathrm{nM}[2,4,6,7-3 \mathrm{H}] \mathrm{E} 2(89 \mathrm{Ci} / \mathrm{mmol}$; Ge Healthcare, Milan, Italy) in the presence or absence of an increasing concentration of nonlabeled competitors (E2, G-1, OHT and MIBE). Then, cells were incubated for two hours at $37^{\circ} \mathrm{C}$ and washed three times with ice-cold PBS; the radioactivity collected by $100 \%$ ethanol extraction was measured by liquid scintillation counting. Competitor binding was expressed as a percentage of maximal specific binding. Each point is the mean of three observations.

\section{Reverse transcription and real-time PCR}

Gene expression was evaluated by real-time PCR as we previously described [37]. For Cyclin D1, IRS-1, PR, pS2, c-fos, CTGF, Cyr61, EGR1, and the ribosomal protein $18 \mathrm{~S}$, which was used as a control gene to obtain normalized values, the primers were: 5'-GTCTGTGCAT 'TTCTGGTTGCA-3' (Cyclin D1 forward) and 5'GCTGGAAACATGCCGGTTA-3' (Cyclin D1 reverse); 5'-GCCCGTGTTACTGTTCATTCAG-3' (IRS-1 forward) and 5'-AATAACGGACACTGCACAACAGTCT3' (IRS-1 reverse); 5'-GAGTTGTGAGAGCACTGGATGCT-3' (PR forward) and 5'-CAACTGTAT GTCTTGACCTGGTGAA-3' (PR reverse); 5'-GCCCCC CGTGAAAGAC-3' (pS2 forward) and 5'-CGTCGAAACAGCAGCCCTTA-3' (pS2 reverse); 5'-CGAGCCCT TTGATGACTTCCT-3' (c-fos forward), 5'-GGAGCGG GCTGTCTCAGA-3' (c-fos reverse); 5'-ACCTGTG GGATGGGCATCT-3' (CTGF forward), 5'-CAGGC GGCTCTGCTTCTCTA-3' (CTGF reverse); 5'-GAGT GGGTCTGTGACGAGGAT-3' (Cyr61 forward) and 5'GGTTGTATAGGATGCGAGGCT-3' (Cyr61 reverse); 5'-GCCTGCGACATCTGTGGAA-3' (EGR1 forward), 5'-CGCAAGTGGATCTTGGTATGC-3' (EGR1 reverse); and 5'- GGCGTCCCCCAACTTCTTA -3' (18S forward) and 5'- GGGCATCACAGACCTGTTATT -3' (18S reverse), respectively.

\section{Western blotting}

Cells were grown in 10-cm dishes, exposed to ligands, and then lysed in $500 \mu \mathrm{L}$ of $50 \mathrm{mmol} / \mathrm{L} \mathrm{NaCl}, 1.5$ $\mathrm{mmol} / \mathrm{L} \mathrm{MgCl2}, 1 \mathrm{mmol} / \mathrm{L}$ EGTA, 10\% glycerol, 1\% 
Triton X-100, 1\% sodium dodecyl sulfate (SDS), and a mixture of protease inhibitors containing $1 \mathrm{mmol} / \mathrm{L}$ aprotinin, $20 \mathrm{mmol} / \mathrm{L}$ phenylmethylsulfonyl fluoride and $200 \mathrm{mmol} / \mathrm{L}$ sodium orthovanadate. Protein concentration was determined using Bradford reagent according to the manufacturer's recommendations (Sigma-Aldrich, Milan, Italy). Equal amounts of whole protein extract were resolved on a $10 \%$ SDS-polyacrylamide gel, transferred to a nitrocellulose membrane (GE Healthcare, Milan, Italy), probed overnight at $4{ }^{\circ} \mathrm{C}$ with antibodies against Cyclin D1 (M-20), IRS-1 (A-19), c-fos (H-125), CTGF (L-20), GPER (N-15), pEGFR Tyr 1173 (sc12351), $\beta$-actin (C-2), phosphorylated ERK1/2 (E-4) and ERK2 (C-14) (all purchased from Santa Cruz Biotechnology, DBA, Milan, Italy), and then revealed using the ECL ${ }^{\mathrm{TM}}$ Western Blotting Analysis System (GE Healthcare, Milan, Italy).

\section{Proliferation assay}

For quantitative proliferation assay, cells $\left(1 \times 10^{5}\right)$ were seeded in 24-well plates in regular growth medium. Cells were washed once they had attached and then were incubated in medium containing $2.5 \%$ charcoalstripped FBS with the indicated treatments; medium was renewed every two days (with treatments) before counting, using the Countess Automated Cell Counter, as recommended by the manufacturer's protocol (Invitrogen S.r.l., Milan, Italy).

\section{Statistical analysis}

Statistical analysis was done using ANOVA followed by Newman-Keuls' testing to determine differences in means. $P<0.05$ was considered as statistically significant.

\section{Results}

Molecular modeling and binding assays demonstrate that MIBE is a ligand of both ER $\alpha$ and GPER

On the basis of the results obtained in docking simulations as described in the Materials and methods section, we evaluated the affinity of MIBE for the ligand binding pockets of both ER $\alpha$ and GPER with respect to E2 and G-1, respectively (Figure 2). Docking E2 to the hormone binding pocket of a closed conformation of ER $\alpha$ (Figure $2 a)$, we observed a binding mode similar to that reported in the experimental crystallographic complex (superposition of the solution provided by GOLD to the crystallographic structure led to a RMSD of $0.092 \AA$ ) [32]. Docking MIBE to the same pocket using ER $\alpha$ in both the closed and open conformation, we evidenced a better affinity for the last conformation (Figure $2 b$ ) and a binding mode similar to that adopted by the ER antagonist $\mathrm{OHT}$ in the crystallographic structure (PDB code 3ERT) [33].
As it concerns the GPER ligand binding pocket, visual inspection showed that it lies within a deep cleft in where 10 hydrophobic residues (V116, Met133, Leu137, Phe206, Phe208, Phe 278, Ile279, Ile308, Val309 and Phe314) and 5 polar amino acids (Tyr123, Gln138, Asp210, Glu275 and His282) contribute to stabilize the ligands through Van der Waals interactions and hydrogen bonds, respectively. Using GPER as a target, docking simulations confirmed a good affinity of the protein for the agonist G-1 (Figure 2c) as previously demonstrated both in silico and in vitro [29]. Next, we docked MIBE to GPER using the same settings and parameters as for G-1. MIBE, which was positioned within the GPER binding site (Figure 2d), displayed a high affinity for GPER, even better than that exhibited by G-1. In particular, MIBE binds to GPER forming hydrogen bonds with the hydroxyl groups located on its branched arms, on one side with Y123 OH, on the other with Q215 NE2 and H282 ND1 atoms. MIBE is also stabilized in the protein binding pocket by Van der Waals interactions of its methyl groups with residues F208, I279, T305 and I308, while a $\pi-\pi$ stacking interaction is formed by the aromatic rings of F208 and the indole ring of MIBE. Starting from the aforementioned observations, we performed diverse assays to fully evaluate the ligand binding properties and the potential agonist/antagonist activity of MIBE exerted through ER $\alpha$ and GPER.

In order to confirm whether MIBE is a ligand of ER $\alpha$, we performed competitive binding experiments by using the recombinant ER $\alpha$ protein. MIBE displaced the radiolabeled E2 in a dose-dependent manner (Figure 3a) indubitably demonstrating its capability to bind to ER $\alpha$ in a direct fashion, although with a lower binding affinity in respect to $\mathrm{E} 2$ and $\mathrm{OHT}$ as $10 \mu \mathrm{M}$ MIBE induced approximately $40 \%$ displacement of $[3 \mathrm{H}] \mathrm{E} 2$. On the basis of the ability of MIBE to interact with GPER in docking simulations, we also performed ligand binding studies using radiolabeled E2 as a tracer in ER-negative but GPER-positive SkBr3 breast cancer cells, as previously reported [28]. Hence, we performed binding experiments using cold E2, MIBE, the selective GPER ligand G-1 and OHT, which has been largely reported to act as a GPER agonist [7]. Interestingly, MIBE showed the capability to displace [3H]E2 (Figure $3 \mathrm{~b}$ ) in accordance with the results obtained in docking simulations. E2, G-1 and OHT confirmed the ability to compete with $[3 \mathrm{H}] \mathrm{E} 2$ as previously shown [28]. Collectively, our findings demonstrate that MIBE is a ligand of both $\mathrm{ER} \alpha$ and GPER.

\section{MIBE inhibits both ER transactivation and gene expression induced by E2}

On the basis of these results, we aimed to ascertain whether MIBE could function as an agonist or 

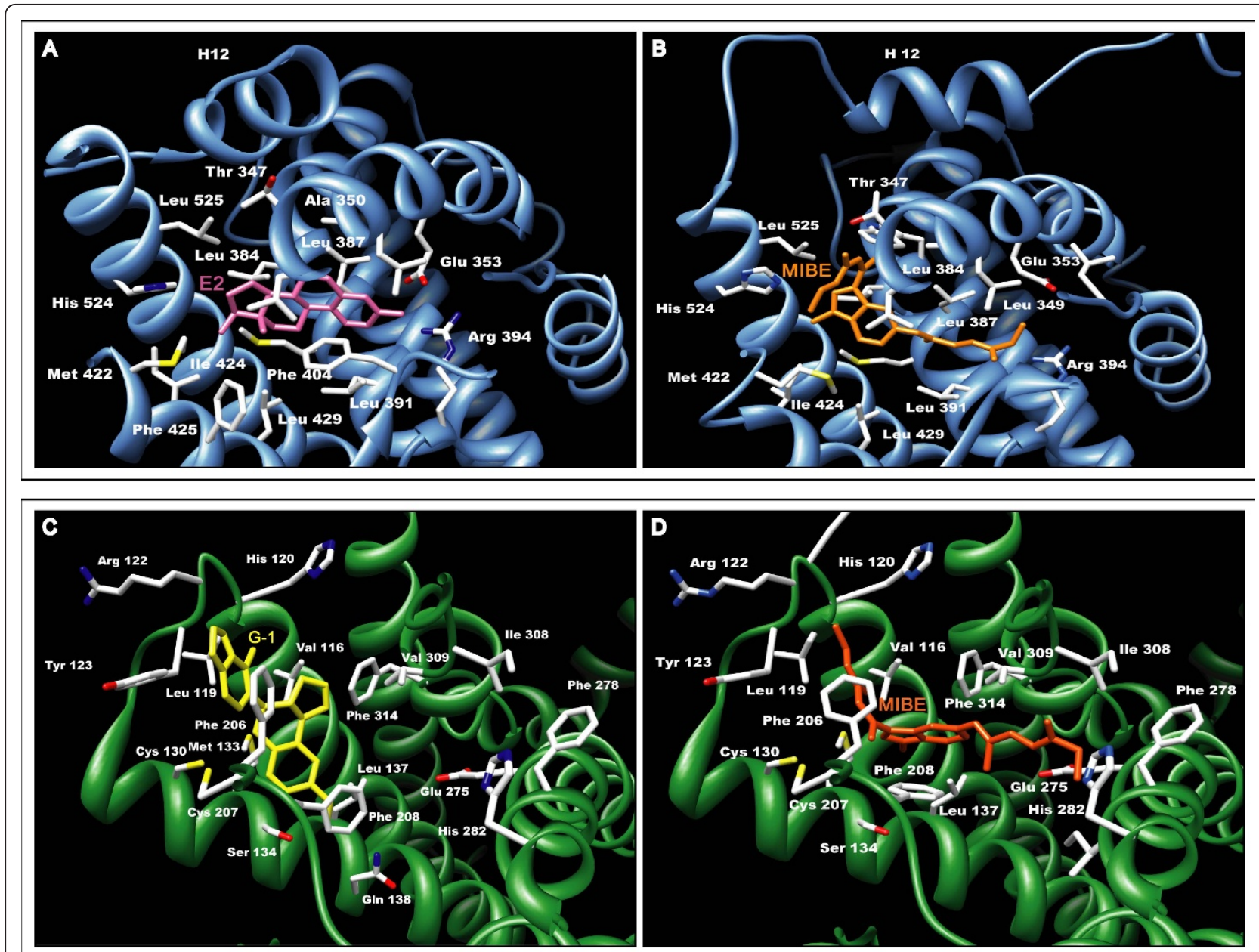

Figure 2 GPER and ERalpha docking simulations. (a-b) The three-dimensional model of ERalpha is schematically reported as a light blue ribbon cartoon; residues involved in ligand binding are drawn as sticks. (a) The binding modes of E2 (pink sticks) to ERalpha in the "closed conformation" is shown. (b) The MIBE moiety (orange sticks) is drawn in its favorable conformation bound to ERalpha (open conformation), with the helix 12 displaced with respect to the position exhibited in the ERalpha-E2 complex. (c-d) The GPER model is reported as green ribbon and residues involved in ligand binding are drawn as sticks. (c) G-1 is drawn in yellow. (d) The MIBE moiety is drawn as orange sticks.

antagonist for ER $\alpha$ and GPER. Initially, we evaluated the potential of MIBE in activating or inhibiting the $E R \alpha$-mediated signaling. Hence, we transiently transfected an ER-reported gene in MCF7 breast cancer cells, which express ER $\alpha$ but not ER $\beta$ as judged by RT-PCR (data not shown). The reporter plasmid used carries firefly luciferase sequences under the control of an ERE upstream of the thymidine kinase promoter. As an internal transfection control, we co-transfected a plasmid expressing renilla luciferase which is enzymatically distinguishable from firefly luciferase by the strong cytomegalovirus enhancer/promoter. MIBE did not show any capability to transactivate ER $\alpha$; however, it abrogated the luciferase activity induced by E2 like the ER antagonist OHT (Figure $4 \mathrm{a}, \mathrm{b}$ ). To confirm these data and to examine the response of $E R \beta$, we transiently transfected the ER-negative Hek293 cells with chimeric proteins consisting of the DNA binding domain (DBD) of the yeast transcription factor Gal4 and the ligand binding domain (LBD) of ER $\alpha$ (GalER $\alpha)$ or ER $\beta$ (GalER $\beta$ ), respectively. MIBE did not activate GalER $\alpha$ and GalER $\beta$ (Figure 4c, d), but prevented the transactivation of these chimeric proteins by E2 mimicking the inhibitory activity of OHT (Figure 4e, f). In order to evaluate whether MIBE acts through a further member of the steroid receptor superfamily as the AR, we transiently transfected the ER-negative Hek293 cells with an AR reporter gene along with the expression vector encoding AR. DHT transactivated the AR reporter gene, whereas MIBE neither activated AR nor prevented the DHT-induced activation of AR (Additional file 1). Together, these results provide 

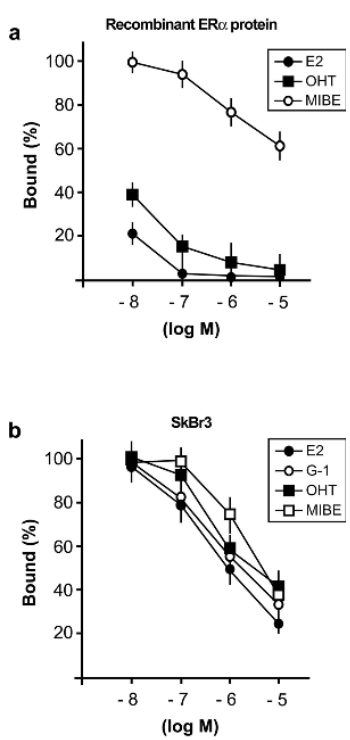

Figure 3 MIBE is a ligand of GPER and ERalpha. (a) MIBE competes with $[3 \mathrm{H}] \mathrm{E} 2$ for the binding to ERalpha. Competitive binding of increasing concentrations of unlabelled E2, OHT and MIBE to recombinant human ERalpha protein. Each data point represents the mean \pm SD of triplicate samples of three separate experiments. (b) Ligand binding assay in $\mathrm{SkBr} 3$ cells. Competition curves of increasing concentration of unlabelled E2, G-1, OHT and MIBE expressed as a percentage of maximum specific [3H]E2 binding. Each data point represents the mean \pm SD of three separate experiments performed in triplicate.

evidence regarding the specific action of MIBE on ERmediated signaling.

In order to further demonstrate that MIBE acts as an $E R \alpha$ antagonist, we evaluated its ability to repress in MCF7 cells the mRNA expression of well known E2 target genes like pS2, Cyclin D1, PR and IRS-1. As determined by real-time PCR, the E2-dependent increase of all genes examined was prevented by MIBE as obtained using OHT (Figure 5a). Similarly, the protein expression of cyclin D1 and IRS-1 induced by E2 in MCF7 cells was inhibited by MIBE (and OHT) (Figure 5b, c).

\section{MIBE prevents the proliferative effects triggered by E2}

Considering that the regulation of estrogen target genes connects the signaling of E2 with the proliferation of breast cancer cells [40,41], we wanted to determine the biological significance of the antagonist action elicited by MIBE through ER $\alpha$. MIBE as OHT did not stimulate growth effects used alone (Figure $5 \mathrm{~d})$; however, both compounds abolished the proliferation of MCF7 cells induced by E2 (Figure 5e). Hence, MIBE can be considered as an ER antagonist on the basis of its full inhibitory activity elicited on ERmediated signaling.

\section{MIBE prevents the GPER-mediated EGFR and ERK} activation

Having established that MIBE is an inhibitor of $E R \alpha$, we aimed to determine its functional activity on the GPERmediated transduction pathway. Previous studies have indicated that GPER activation triggers the EGFRdependent signaling in cancer cells, even involving a functional cross-talk between these receptors $[8,9,23]$. Then, we sought to evaluate the role played by GPER in EGFR phosphorylation upon exposure to its cognate ligand. Notably, in SkBr3 cells the EGFR activation induced by EGF was prevented by knocking down GPER expression (Figure 6a-d) as observed in the presence of MIBE (Figure 6e, f), which further demonstrated that it acts as an inhibitor of GPER-mediated function. Accordingly, the activation of EGFR triggered by G-1 was abolished in the presence of MIBE, hence confirming its inhibitory activity on GPER-mediated signaling (Additional file 2). Corroborating the aforementioned findings, MIBE showed the capability to inhibit the ERK activation upon EGF exposure (Figure $6 \mathrm{~g}$, $\mathrm{h}$ ) as well as by the GPER activators E2, G-1 and OHT (Figure 6i-1). Overall, these results suggest that MIBE acting as an inhibitor of GPER blocks the EGFR activation and the ERK phosphorylation induced by EGF and the ligands of GPER, thus preventing the functional crosstalk between GPER and EGFR.

\section{MIBE inhibits gene transcription and cell proliferation mediated by GPER}

The characterization of the transcriptional response to GPER signaling has recently identified a set of target genes that mediate the stimulatory effects triggered by GPER activation in cancer cells [24]. Hence, we performed real-time PCR experiments to evaluate the potential of MIBE in regulating the expression of GPERdependent genes. Of note, the up-regulation of c-fos, CTGF, Cyr61 and EGR1 induced by the GPER agonists E2, G-1 and OHT in SKBr3 cells was abolished in the presence of MIBE (Figure 7a). In accordance with these results, MIBE also prevented the increase of both c-fos and CTGF at the protein level (Figure 7b, c). Next, we wondered what might be the biological significance of the inhibitory action of MIBE through GPER signaling. As shown in panel $d$ of Figure 7, the proliferative effects elicited by E2, G-1 and OHT in SKBr3 cells were inhibited by MIBE. Altogether, these findings demonstrate that MIBE acts as an antagonist of both ER $\alpha$ and GPER in breast cancer cells.

\section{Discussion}

In the present study, we identified the first ligand of ER $\alpha$ and GPER, referred to as MIBE, which acts as an 
EREluc
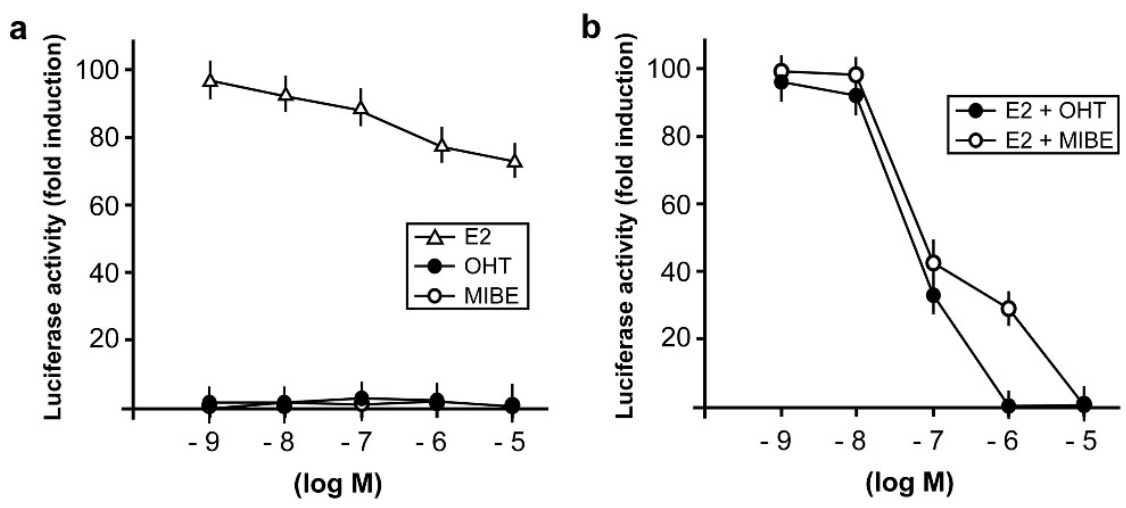

GalER $\alpha$ LBD
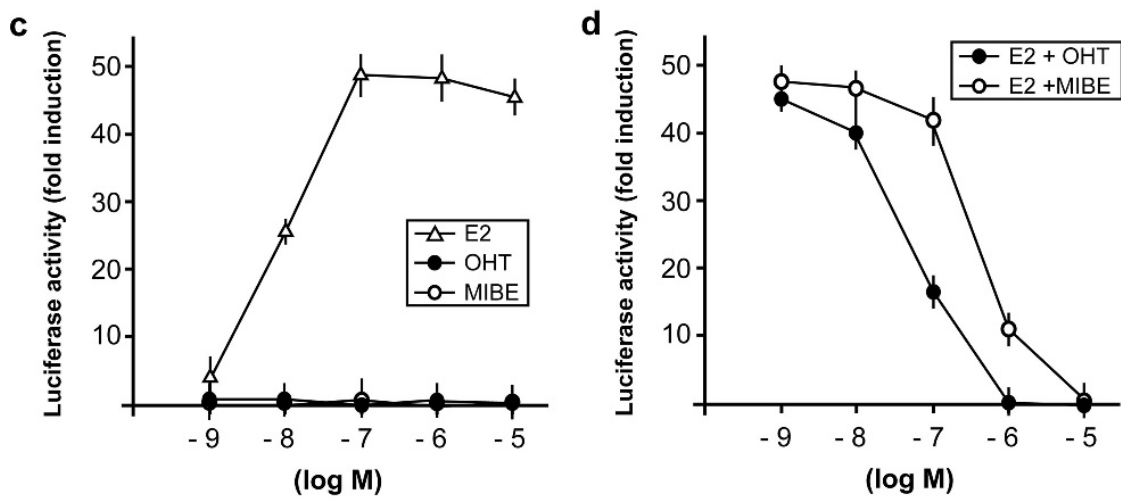

GaIER $\beta$ LBD
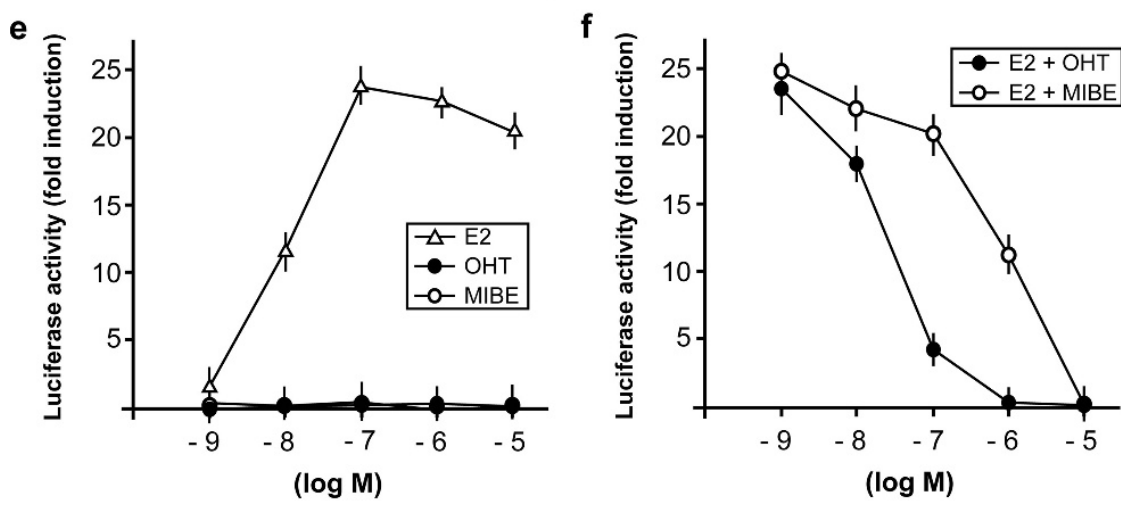

Figure 4 MIBE inhibits the transactivation of ERalpha induced by E2. (a) MCF7 cells were transfected with the ER luciferase reporter gene (EREluc) along with the internal transfection control Renilla Luciferase and treated with increasing concentrations (logarithmic scale) of E2, the ER antagonist OHT and MIBE. (b) MCF7 cells were transfected with the ER reporter gene and the internal transfection control Renilla Luciferase and treated with $10 \mathrm{nM}$ E2 in combination with increasing concentration of OHT or MIBE, as indicated. (c, e) Hek293 cells were transfected with Gal4 reporter gene GK1, the Gal4 fusion proteins encoding the Ligand Binding Domain (LBD) of ERo (GalERalpha) or ERbeta (GalERbeta) and the internal transfection control Renilla Luciferase and treated with increasing concentrations (logarithmic scale) of E2, OHT and MIBE. (d, f) Hek293 cells were transfected with the Gal4 reporter gene GK1, the Gal4 fusion proteins GalERalpha or GalERbeta and the internal transfection control Renilla Luciferase and treated with $100 \mathrm{nM}$ E2 in combination with increasing concentrations of OHT or MIBE, as indicated. Each data point represents the mean $\pm \mathrm{SD}$ of three experiments performed in triplicate. 


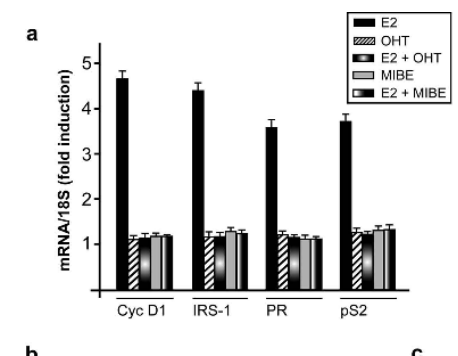

b
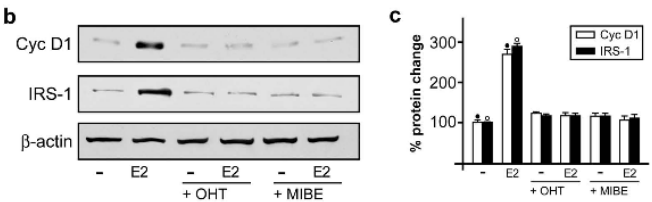

d
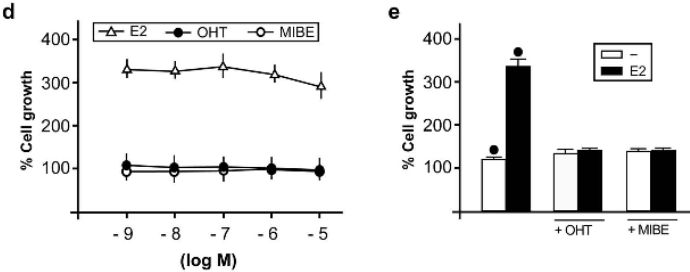

Figure 5 MIBE inhibits gene expression and proliferation induced by E2 in MCF7 cells. (a) Evaluation of mRNA expression of Cyclin D1 (Cyc D1), IRS-1, Progesterone Receptor (PR) and pS2 by real-time PCR in MCF7 cells. Cells were treated for $24 \mathrm{~h}$ with vehicle, $10 \mathrm{nM}$ E2, 1 microM OHT and 10 microM MIBE alone or in combination, as indicated. Results obtained from experiments performed in triplicate were normalized for $18 \mathrm{~S}$ expression and shown as fold change of RNA expression compared to cells treated with vehicle. Each data point represents the mean \pm SD of three independent experiments performed in triplicate. (b) Immunoblots of protein levels of Cyclin D1 (Cyc D1) and IRS-1 from MCF7 cells. Cells were treated for $24 \mathrm{~h}$ with vehicle (-), $10 \mathrm{nM} \mathrm{E2,} 1$ microM $\mathrm{OHT}$ and 10 microM MIBE alone or in combination, as indicated. $\beta$ actin serves as loading control. Data shown are representative of three independent experiments. (c) Densitometric analysis of three independent experiments, protein expressions are normalized to beta-actin. $(\cdot),(\circ)$ indicate $P<0.05$ for cells receiving vehicle versus treatments. (d) MCF7 cells were treated for five days with vehicle, increasing concentrations (logarithmic scale) of E2, OHT and MIBE and counted on Day 6. (e) Cells were treated for five days with vehicle (-), 10 nM E2, 1 microM OHT and 10 microM MIBE alone or in combination, as indicated, and then the proliferation was evaluated by cell counts on Day 6. The proliferation of cells receiving vehicle was set as $100 \%$ upon which cell growth induced by treatments was calculated. Each data point is the average $\pm \mathrm{SD}$ of three independent experiments performed in triplicate. $(\cdot)$ indicates $P<0.05$ for cells receiving vehicle $(-)$ versus treatments.

antagonist of both receptors in breast cancer cells. By molecular modeling and binding experiments we demonstrated that MIBE binds to both receptors, while through functional assays we showed that MIBE inhibits the ER $\alpha$ - and GPER-mediated signaling. In particular, using the ER-positive MCF7 and ER-negative $\mathrm{SkBr} 3$ breast cancer cells as a model system, we characterized the biological properties of MIBE. We found that in MCF7 cells MIBE blocks the ER

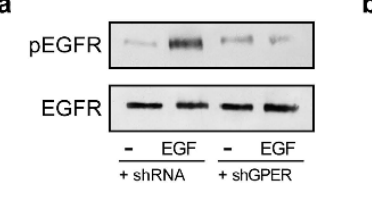

c
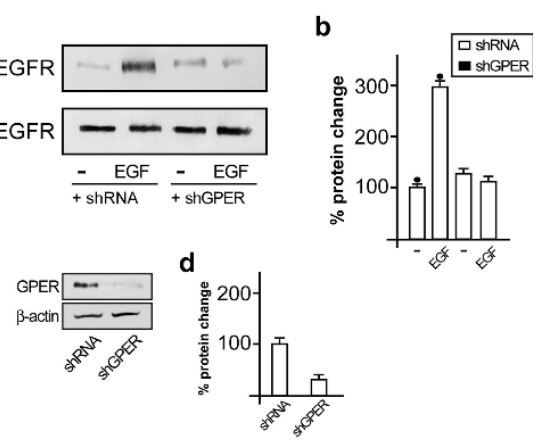

e
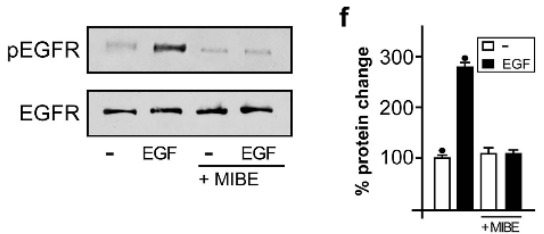

g

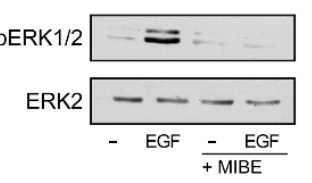

h

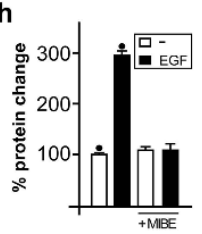

i

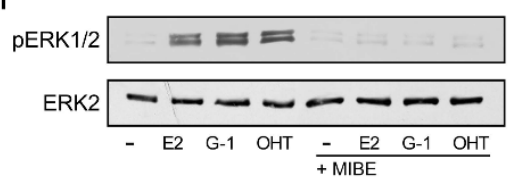

I

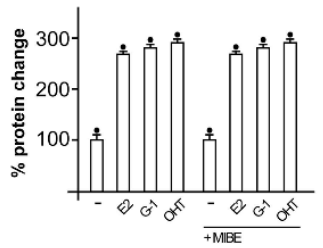

Figure 6 MIBE prevents the phosphorylation of EGFR and ERK1/2. (a) EGFR ${ }^{\text {Tyr1173 }}$ phosphorylation after treatment (five minutes) with vehicle (-) and $100 \mathrm{ng} / \mathrm{ml} \mathrm{EGF}$ in $\mathrm{SkBr} 3$ cells transfected with shRNA or shGPER. (b) Densitometric analysis of three independent experiments, EGFR ${ }^{\text {Tyr1173 }}$ expressions are normalized to EGFR. (c) Efficacy of GPER silencing obtained using shGPER. (d) Densitometric analysis of three independent experiments. GPER expressions are normalized to beta-actin. (e) EGFR ${ }^{\text {Tyr1173 }}$ phosphorylation after treatment (five minutes) with vehicle (-) and $100 \mathrm{ng} / \mathrm{ml}$ EGF alone and in combination with 10 $\mu \mathrm{M}$ MIBE. (f) Densitometric analysis of three independent experiments. EGFR ${ }^{\text {Tyr1173 }}$ expressions are normalized to EGFR. (g) ERK1/2 activation in SkBr3 cells treated for five minutes with vehicle (-) or $100 \mathrm{ng} / \mathrm{ml} \mathrm{EGF}$ alone and in combination with 10 microM MIBE. (h) Densitometric analysis of three independent experiments. ERK1/2 expressions are normalized to ERK2. (i) ERK1/2 activation in $\mathrm{SkBr} 3$ cells treated for 15 minutes with vehicle (-), $100 \mathrm{nM} \mathrm{E2,1}$ microM G-1 and 5 microM OHT alone and in combination with 10 microM MIBE. Data shown are representative of three independent experiments. (i) Densitometric analysis of three independent experiments. ERK1/2 expressions are normalized to ERK2. (•) indicates $P<0.05$ for cells receiving vehicle versus treatments. 


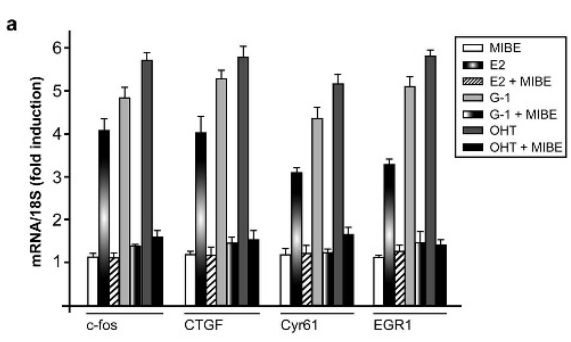

b
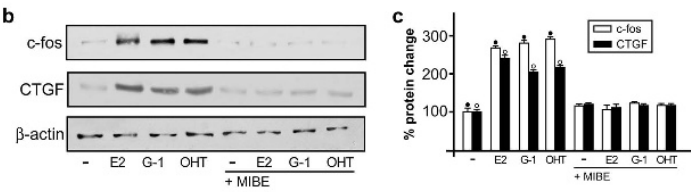

d

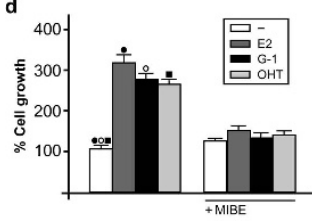

Figure 7 MIBE inhibits GPER target genes and proliferation induced by E2, G-1 and OHT. (a) The expression of c-fos, CTGF, Cyr61 and EGR1 induced in SkBr3 cells by $1 \mathrm{~h}$ treatment with 100 $\mathrm{nM}$ E2, 1 microM G-1 and 5 microM OHT is inhibited in presence of 10 microM MIBE, as evaluated by real-time PCR. Results obtained from experiments performed in triplicate were normalized for $18 \mathrm{~S}$ expression and shown as fold change of RNA expression compared to cells treated with vehicle. Each data point represents the mean \pm SD of three independent experiments performed in triplicate. (b) The up-regulation of c-fos and CTGF protein levels induced in $\mathrm{SkBr3}$ cells by 2 h treatment with 100 nM E2, 1 microM G-1 and 5 microM $\mathrm{OHT}$ were abolished in presence of 10 microM MIBE. Data shown are representative of three independent experiments. beta-actin serves as a loading control. (c) Densitometric analysis of c-fos and CTGF protein expressions normalized to beta-actin. $(\cdot)$, (०) indicate $P$ $<0.05$ for cells receiving vehicle versus treatments. (d) The proliferation of $\mathrm{SkBr} 3$ cells upon treatment with $100 \mathrm{nM}$ E2, $100 \mathrm{nM}$ G-1 and 100 nM OHT was inhibited by 1 microM MIBE, as indicated. Cells were treated for five days with the indicated treatments and counted on Day 6. Proliferation of cells receiving vehicle was set as $100 \%$ upon which cell growth induced by treatments was calculated. Each data point is the average \pm SD of three independent experiments performed in triplicate. $(\cdot),(\circ),(\cdot)$, indicate $P<0.05$ for cells receiving vehicle $(-)$ versus treatments.

transactivation induced by E2 as well as the ERmediated gene regulation and cell proliferation. In addition, in SkBr3 cells MIBE prevented the GPERdependent responses, such as rapid ERK phosphorylation, gene transcription and growth effects induced by the GPER agonists E2, OHT and G-1. The exclusive antagonistic action exerted by MIBE on both ER $\alpha$ and GPER could represent a novel promising tool for a more comprehensive pharmacological approach in estrogen-dependent tumors like breast cancer, which express one or both receptors from the onset or following tumor progression.
Breast cancer is the most commonly diagnosed invasive malignancy and the second leading cause of cancer death in women [42]. Endocrine treatment along with surgery, chemotherapy, radiotherapy and targeted therapy are fundamental modalities for the therapeutic management of breast cancer. The expression of ER $\alpha$ in breast carcinomas correlates with the beneficial response to anti-estrogens [43], whereas the lacking of ER $\alpha$ is coupled to a worse prognosis and to short disease-free survival rates [44]. On the basis of the main role exerted by ER $\alpha$ in the development and progression of breast cancer and considering that this receptor is expressed in approximately $70 \%$ of breast tumors, the ER antagonist tamoxifen has been widely used, although its effectiveness is limited by de novo and acquired resistance [45]. In accordance with these data, comparative clinical studies have indicated that aromatase inhibitors blocking estrogen biosynthesis may provide major benefits in respect to ER $\alpha$ antagonists in breast cancer patients [46]. Among the various mechanisms involved in the resistance to endocrine treatment, the activation of transduction pathways different from those mediated by $E R \alpha$ has been proposed. For instance, an increased expression and/or activation of growth factor receptors, such as EGFR/HER2, have been associated with the failure of endocrine therapy in breast tumors [47]. Moreover, the existence of alternative ERs able to mediate estrogen signaling without exhibiting any sensitivity to the repressive action of the ER antagonists could be also involved in the resistance to endocrine agents. In this scenario, it has been recently demonstrated that GPER acts as an additional receptor mediating the effects of estrogens in a wide number of cell types, such as breast, endometrial and ovarian cancer cells [7]. Of note, diverse studies have shown that E2 as well as the antiestrogens tamoxifen and ICI bind to and activate GPER signaling, including ERK phosphorylation and gene transcription, which in turn lead to cancer cell proliferation and migration [7].

The activation of the GPER transduction pathway requires the EGFR transactivation [8], in accordance with evidence showing that the agonist stimulation of diverse G-protein coupled receptors (GPCRs) triggers the transactivation of EGFR through the release of EGFlike ligands tethered at the cell surface and the subsequent generation of intracellular signaling [48]. In addition, the functional crosstalk which occurs between members of GPCR and growth factor receptor families contributes to the progression of different tumors $[8,48]$. In this regard, we have previously reported that GPER and EGFR physically and functionally interact in both ER-negative and ER-positive cancer cells [22,23]. Recently, it has also been found that a crosstalk among EGFR, the nerve growth factor (NGF) receptor TrkA 
and the GPCR Formyl Peptide Receptor (FPR) occurs in monocytes [49]. In particular, the inhibition of EGFR prevented the ligand-dependent responses mediated by the other two receptors, while the inhibition of FPR abolished the EGFR and TrkA phosphorylation induced by EGF and NGF, respectively. Accordingly, the silencing of each receptor suppressed the capability of the other receptors to mediate the ligand-induced actions like ERK phosphorylation [49]. In line with these findings, our current results provide novel insight into the functional crosstalk between GPER and EGFR in cancer cells. Notably, we show for the first time that the activation of EGFR induced by its cognate ligand EGF is abolished by knocking down GPER expression or in the presence of MIBE, which is an inhibitor of GPER as ascertained in the present study. Nevertheless, further studies are needed to better understand the role played by GPER in the activation of EGFR by its cognate ligand EGF and to appreciate the potential of MIBE in preventing the crosstalk between GPER and EGFR which was previously well described [23].

On the basis of these remarks, it remains to be evaluated that the potential of MIBE to interfere with the functional crosstalk between EGFR and ER $\alpha$, toward a better characterization of its inhibitory activity elicited in cell contexts expressing both receptors. In particular, considering that a physical and functional interaction between EGFR and ER leads to the activation of multiple intracellular cascades, including MAPK, phosphoinositide 3-kinase (PI3K) and other protein kinases [50-53], it would be interesting to ascertain whether MIBE could alter these transduction signals that have been involved in the proliferation of cancer cells [50,54-58].

In 2005, two reports provided evidence on the capability of estrogens and anti-estrogens to bind to GPER $[10,19]$. In particular, the ER antagonists tamoxifen and ICI displayed a high binding affinity for GPER, as assessed in competition assays. Surprisingly, unlike the antagonistic properties exhibited by these agents on the classical ER-mediated pathways, both tamoxifen and ICI act as GPER agonists $[8,9,19]$. In the following years, further ER ligands and activators showed the ability to bind to GPER eliciting promiscuous actions through the two receptors. For instance, the phytoestrogen genistein and the xenoestrogen bisphenol A, which exert estrogen-like activities binding to and activating ER $\alpha[9,59]$, displayed the ability to bind to and activate GPER signaling $[9,27,60]$. As it concerns the pesticide atrazine, it exerted estrogenic effects without binding to ERs [61] and exhibiting the capability to activate the GPERmediated pathway despite a low binding affinity for this receptor [25,27]. Unlike E2 which exhibited ER $\alpha$ and
GPER agonism in several investigations [7], the well known ER $\alpha$ ligand and activator estriol showed antagonistic properties for GPER-mediated signaling [28]. Besides, G-1 [29] and G-15, along with its derivatives $[30,31]$ as ligands activated or inhibited, respectively, the GPER-mediated signaling, while some GPER antagonists triggered at high concentrations ER-dependent transcriptional responses [30].

GPER expression was indicated as a potential predictor of biological aggressive features in breast carcinomas [16]. Although a significant association between ER $\alpha$ and GPER was observed, approximately $50 \%$ of ER $\alpha$ negative breast tumors retained GPER suggesting that the expression of these receptors may not be interdependent [16]. On the basis of these and the aforementioned findings, tumor cells that express GPER but lack ER $\alpha$ may be stimulated by estrogens and even by antiestrogens, such as tamoxifen. In this regard, it should be noted that the stimulatory effects on cancer progression elicited by estrogens via both ER $\alpha$ and GPER and by $E R \alpha$ antagonists through GPER address the need to discover novel drugs targeting simultaneously both receptors, in order to obtain major therapeutic benefits in respect to the use of the current selective antagonists.

\section{Conclusions}

The exclusive antagonistic activity exerted by MIBE on $E R \alpha$ - and GPER-mediated signaling as shown in the present study (Figure 8 ), could represent a promising pharmacological approach either at the beginning or during the progression of breast tumors which express one or both receptors. In this respect, further studies are needed to examine whether MIBE could be considered a useful tool towards a more comprehensive treatment in breast cancer.

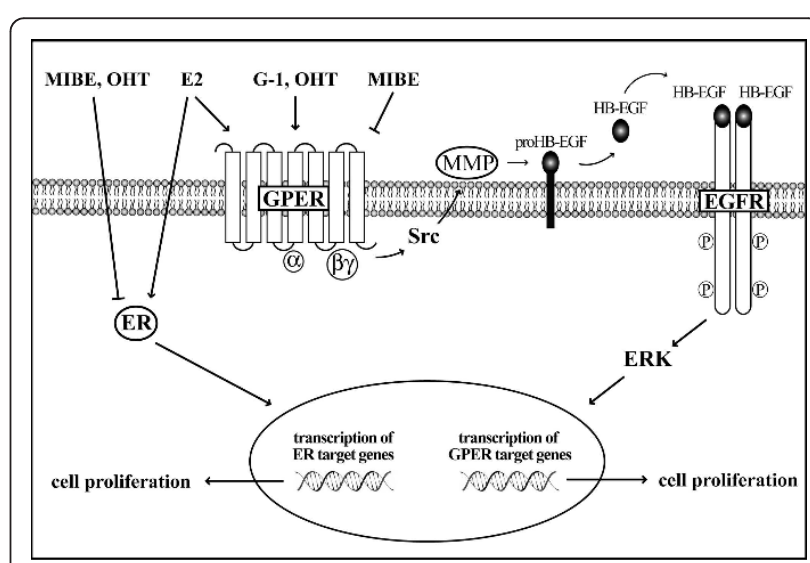

Figure 8 Schematic representation of the inhibitory activity exerted by MIBE on GPER- and ER-mediated signaling. 


\section{Additional material}

Additional file 1: MIBE does not activate AR. Hek293 cells were transfected with AR luciferase reporter gene (ARE-luc) and AR expression plasmid along with the internal transfection control Renilla Luciferase, and treated with $10 \mathrm{nM}$ DHT alone and in combination with $10 \mu \mathrm{M}$ MIBE, as indicated. The normalized luciferase activities of cells treated with vehicle (-) were set as one-fold induction, upon which the activities induced by treatments were calculated. Each data point represents the mean \pm SD of three experiments performed in triplicate.

Additional file 2: MIBE prevents the phosphorylation of EGFR induced by G-1. (a) EGFR ${ }^{\mathrm{Y} y \mathrm{r} 173}$ phosphorylation after treatment (30 minutes) with vehicle (-) and $1 \mu \mathrm{M} \mathrm{G-1}$ alone and in combination with $10 \mu \mathrm{M}$ MIBE. (b) Densitometric analysis of three independent experiments, EGFR ${ }^{T y} 1173$ expressions are normalized to EGFR.

\section{Abbreviations}

AR: androgen receptor; CAFs: cancer associated fibroblasts; CS: charcoalstripped; DBD: DNA binding domain; DHT: 5a-dihydrotestosterone; DMSO: dimethyl sulfoxide; E2: 17ß-estradiol; EGFR: epidermal growth factor receptor; ER: estrogen receptor; ERK: extracellular signal-regulated kinase; FPR: formyl peptide receptor; G-1: 1-[4-(6-bromobenzo[1:3]dioxol-5-yl)-3a:4:5:9btetrahydro-3H-cyclopenta[c]quinolin-8-yl]-ethanone; G-15: 4-(6-Bromobenzo [1:3]dioxol-5-yl)-3a:4:5:9b-tetrahydro-3H-cyclopenta[c]quinoline; GPCRs: Gprotein coupled receptors; GPER: G protein-coupled estrogen receptor; HBEGF: heparan-bound epidermal growth factor; LBD: ligand binding domain; MAPK: mitogen-activated protein kinase; MIBE: ethyl 3-[5-(2-ethoxycarbonyl1-methylvinyloxy)-1-methyl-1H-indol-3-yl]but-2-enoate; NGF: nerve growth factor; OHT: 4-hydroxytamoxifen; PI3K: phophatidylinositol 3-kninase; PLC: phospholipase C; SDS: sodium dodecyl sulfate; TLC: thin layer chromatography.

\section{Acknowledgements}

This work was supported by Associazione Italiana per la Ricerca sul Cancro (AIRC, project n. 8925/2009 and project Calabria 2011), Fondazione Cassa di risparmio di Calabria e Lucania and Ministero dell'Istruzione, dell'Università e della Ricerca (MIUR) (project PRIN 2008PK2WCW/2008).

\section{Author details}

'Dipartimento Farmaco-Biologico, Università della Calabria, via Bucci, 87036 Rende, Italy. ${ }^{2}$ Dipartimento di Scienze Farmaceutiche, Università della Calabria, via Bucci, 87036 Rende, Italy. ${ }^{3}$ U.O.S. Biopolimeri e Proteomica, Azienda Ospedaliera Universitaria IRCCS San Martino IST - Istituto Nazionale per la Ricerca sul Cancro, Largo Benzi 10, 16132 Genova, Italy.

\section{Authors' contributions}

$\mathrm{RL}$ designed and performed the experiments, and wrote the paper. MFS and MP performed the experiments. MSS and AC synthesized MIBE. CR performed docking simulations. MM analyzed data and wrote the paper. All authors read and approved the final manuscript for publication.

\section{Competing interests}

The authors declare that they have no competing interests.

Received: 30 September 2011 Revised: 18 December 2011

Accepted: 17 January 2012 Published: 17 January 2012

\section{References}

1. Deroo BJ, Korach KS: Estrogen receptors and human disease. J Clin Invest 2006, 116:561-570

2. Ascenzi P, Bocedi A, Marino M: Structure-function relationship of estrogen receptor alpha and beta: impact on human health. Mol Aspects Med 2006, 27:299-402.

3. Dupont WD, Page DL: Menopausal estrogen replacement therapy and breast cancer. Arch Intern Med 1991, 151:67-72.

4. Scott JA, McGuire WL: New molecular markers of prognosis in breast cancer. In Endocrine-Dependent Tumors. Edited by: Voigt K-D, Knabbe C. New York: Raven Press; 1991:179-196.
5. Ponzone R, Biglia N, Jacomuzzi ME, Mariani L, Dominguez A, Sismondi P. Antihormones in prevention and treatment of breast cancer. Ann NY Acad Sci 2006, 1089:143-158.

6. Herynk MH, Fuqua SA: Estrogen receptors in resistance to hormone therapy. Adv Exp Med Biol 2007, 608:130-143.

7. Maggiolini M, Picard D: The unfolding stories of GPR30, a new membrane bound estrogen receptor. J Endocrinol 2010, 204:105-114.

8. Filardo EJ, Quinn JA, Bland KI, Frackelton AR Jr: Estrogen-induced activation of Erk-1 and Erk-2 requires the $\mathrm{G}$ protein-coupled receptor homolog, GPR30, and occurs via trans-activation of the epidermal growth factor receptor through release of HB-EGF. Mol Endocrinol 2000, 14:1649-1660.

9. Maggiolini M, Vivacqua A, Fasanella G, Recchia AG, Sisci D, Pezzi V, Montanaro D, Musti AM, Picard D, Andò S: The G protein-coupled receptor GPR30 mediates c-fos up-regulation by 17 beta-estradiol and phytoestrogens in breast cancer cells. J Biol Chem 2004, 279:27008-27016.

10. Thomas $P$, Pang $Y$, Filardo EJ, Dong J: Identity of an estrogen membrane receptor coupled to a $\mathrm{G}$ protein in human breast cancer cells. Endocrinology 2005, 146:624-632.

11. Vivacqua A, Bonofiglio D, Recchia AG, Musti AM, Picard D, Andò S, Maggiolini M: The G protein-coupled receptor GPR30 mediates the proliferative effects induced by $17 \beta$-estradiol and hydroxytamoxifen in endometrial cancer cells. Mol Endocrinol 2006, 20:631-646.

12. Albanito L, Madeo A, Lappano R, Vivacqua A, Rago V, Carpino A, Oprea Tl, Prossnitz ER, Musti AM, Andò S, Maggiolini M: G protein-coupled receptor 30 (GPR30) mediates gene expression changes and growth response to 17beta-estradiol and selective GPR30 ligand G-1 in ovarian cancer cells. Cancer Res 2007, 67:1859-1866.

13. Vivacqua A, Bonofiglio D, Albanito L, Madeo A, Rago V, Carpino A Musti AM, Picard D, Andò S, Maggiolini M: 17ß-Estradiol, genistein, and 4hydroxytamoxifen induce the proliferation of thyroid cancer cells through the G protein coupled-receptor GPR30. Mol Pharmacol 2006, 70:1414-1423.

14. Chan QK, Lam HM, Ng CF, Lee AY, Chan ES, Ng HK, Ho SM, Lau KM: Activation of GPR30 inhibits the growth of prostate cancer cells through sustained activation of Erk1/2, c-jun/c-fos-dependent upregulation of p21, and induction of G(2) cell-cycle arrest. Cell Death Differ 2010, 17:1511-1523.

15. Chevalier N, Bouskine A, Fenichel P: Role of GPER/GPR30 in tumoral testicular germ cells proliferation. Cancer Biol Ther 2011, 12:2-3.

16. Filardo EJ, Graeber CT, Quinn JA, Resnick MB, Giri D, DeLellis RA, Steinhoff MM, Sabo E: Distribution of GPR30, a seven membranespanning estrogen receptor in primary breast cancer and its association with clinicopathologic determinants of tumor progression. Clin Cancer Res 2006, 12:6359-6366.

17. Smith HO, Leslie KK, Singh M, Qualls CR, Revankar CM, Joste NE, Prossnitz ER: GPR30: a novel indicator of poor survival for endometrial carcinoma. Am J Obstet Gynecol 2007, 196:386.e1-9, discussion 386.e9-e11.

18. Smith HO, Arias-Pulido H, Kuo DY, Howard T, Qualls CR, Lee SJ, Verschraegen CF, Hathaway HJ, Joste NE, Prossnitz ER: GPR30 predicts poor survival for ovarian cancer. Gynecol Oncol 2009, 114:465-471.

19. Revankar CM, Cimino DF, Sklar LA, Arterburn JB, Prossnitz ER: A transmembrane intracellular estrogen receptor mediates rapid cell signaling. Science 2005, 307:1625-1630.

20. Prossnitz ER, Maggiolini M: Mechanisms of estrogen signaling and gene expression via GPR30. Mol Cell Endocrinol 2009, 308:32-38

21. Quinn JA, Graeber CT, Frackelton AR Jr, Kim M, Schwarzbauer JE, Filardo EJ: Coordinate regulation of estrogen-mediated fibronectin matrix assembly and epidermal growth factor receptor transactivation by the $\mathrm{G}$ proteincoupled receptor, GPR30. Mol Endocrinol 2009, 23:1052-1064.

22. Albanito L, Sisci D, Aquila S, Brunelli E, Vivacqua A, Madeo A, Lappano R, Pandey DP, Picard D, Mauro L, Andò S, Maggiolini M: Epidermal growth factor induces $\mathrm{G}$ protein-coupled receptor 30 expression in estrogen receptor-negative breast cancer cells. Endocrinology 2008, 149:3799-3808.

23. Vivacqua A, Lappano R, De Marco P, Sisci D, Aquila S, De Amicis F, Fuqua SA, Andò S, Maggiolini M: G protein-coupled receptor 30 expression is up-regulated by EGF and TGF alpha in estrogen receptor alpha-positive cancer cells. Mol Endocrinol 2009, 23:1815-1826.

24. Pandey DP, Lappano R, Albanito L, Madeo A, Maggiolini M, Picard D: Estrogenic GPR30 signalling induces proliferation and migration of breast cancer cells through CTGF. EMBO J 2009, 28:523-532. 
25. Albanito L, Lappano R, Madeo A, Chimento A, Prossnitz ER, Cappello AR, Dolce V, Abonante S, Pezzi V, Maggiolini M: G-protein-coupled receptor 30 and estrogen receptor-alpha are involved in the proliferative effects induced by atrazine in ovarian cancer cells. Environ Health Perspect 2008, 116:1648-1655.

26. Madeo A, Maggiolini M: Nuclear alternate estrogen receptor GPR30 mediates 17beta-estradiol-induced gene expression and migration in breast cancer-associated fibroblasts. Cancer Res 2010, 70:6036-6046.

27. Thomas $P$, Dong J: Binding and activation of the seven-transmembrane estrogen receptor GPR30 by environmental estrogens: a potential novel mechanism of endocrine disruption. J Steroid Biochem Mol Biol 2006, 102:175-179.

28. Lappano R, Rosano C, De Marco P, De Francesco EM, Pezzi V, Maggiolini M: Estriol acts as a GPR30 antagonist in estrogen receptor-negative breast cancer cells. Mol Cell Endocrinol 2010, 320:162-170.

29. Bologa CG, Revankar CM, Young SM, Edwards BS, Arterburn JB, Kiselyov AS, Parker MA, Tkachenko SE, Savchuck NP, Sklar LA, Oprea TI, Prossnitz ER: Virtual and biomolecular screening converge on a selective agonist for GPR30. Nat Chem Biol 2006, 2:207-212.

30. Dennis MK, Field AS, Burai R, Ramesh C, Petrie WK, Bologa CG, Oprea TI, Yamaguchi Y, Hayashi SI, Sklar LA, Hathaway HJ, Arterburn JB, Prossnitz ER Identification of a GPER/GPR30 antagonist with improved estrogen receptor counterselectivity. J Steroid Biochem Mol Biol 2011, 127:358-366.

31. Ramesh C, Nayak TK, Burai R, Dennis MK, Hathaway HJ, Sklar LA, Prossnitz ER, Arterburn JB: Synthesis and characterization of iodinated tetrahydroquinolines targeting the $\mathrm{G}$ protein-coupled estrogen receptor GPR30. J Med Chem 2010, 53:1004-1014.

32. Eiler S, Gangloff M, Duclaud S, Moras D, Ruff M: Overexpression, purification, and crystal structure of native ERa LBD. Protein Expr Purif 2001, 22:165-173.

33. Shiau AK, Barstad D, Loria PM, Cheng L, Kushner PJ, Agard DA, Greene GL: The structural basis of estrogen receptor/coactivator recognition and the antagonism of this interaction by tamoxifen. Cell 1998, 95:927-937.

34. Pettersen EF, Goddard TD, Huang CC, Couch GS, Greenblatt DM, Meng EC, Ferrin TE: UCSF Chimera-a visualization system for exploratory research and analysis. J Comput Chem 2004, 25:1605-1612.

35. Potdar MK, Mohile SS, Salunkhe MM: Coumarin syntheses via Pechmann condensation in Lewis acidic chloroaluminate ionic liquid. Tetrahedron Lett 2001, 42:9285-9287.

36. Subhas Bose D, Rudradas AP, Hari Babu M: The indium(III) chloridecatalyzed von Pechmann reaction: a simple and effective procedure for the synthesis of 4-substituted coumarins. Tetrahedron Lett 2002, 43:9195-9197.

37. Lappano R, Recchia AG, De Francesco EM, Angelone T, Cerra MC, Picard D, Maggiolini M: The cholesterol metabolite 25-hydroxycholesterol activates estrogen receptor a-mediated signaling in cancer cells and in cardiomyocytes. PLoS One 2011, 6:e16631

38. Maggiolini M, Recchia AG, Carpino A, Vivacqua A, Fasanella G, Rago V, Pezzi V, Briand PA, Picard D, Andò S: Oestrogen receptor beta is required for androgen-stimulated proliferation of LNCaP prostate cancer cells. J Mol Endocrinol 2004, 32:777-791.

39. Lanzino M, Sisci D, Morelli C, Garofalo C, Catalano S, Casaburi I, Capparelli C, Giordano C, Giordano F, Maggiolini M, Andò S: Inhibition of cyclin D1 expression by androgen receptor in breast cancer cells-identification of a novel androgen response element. Nucleic Acids Res 2010, 38:5351-5365.

40. Altucci L, Addeo R, Cicatiello L, Dauvois S, Parker MG, Truss M, Beato M, Sica $V$, Bresciani F, Weisz A: 17 $\beta$-Estradiol induces cyclin D1 gene transcription, p36D1-p34cdk4 complex activation and p105Rb phosphorylation during mitogenic stimulation of $\mathrm{G}(1)$-arrested human breast cancer cells. Oncogene 1996, 12:2315-2324

41. Morelli C, Garofalo C, Bartucci M, Surmacz E: Estrogen receptor-alpha regulates the degradation of insulin receptor substrates 1 and 2 in breast cancer cells. Oncogene 2003, 22:4007-4016.

42. Coughlin SS, Ekwueme DU: Breast cancer as a global health concern. Cancer Epidemiol 2009, 33:315-318.

43. Gaskell DJ, Hawkins RA, Sangsterl K, Chetty U, Forrest APM: Relation between immunocytochemical estimation of oestrogen receptor in elderly patients with primary breast cancer and response to tamoxifen. Lancet 1989, 1:1044-1046
44. Mason BH, Holdaway TM, Mullins PR, Yee LH, Kay RG: Progesterone and estrogen receptors as prognostic variables in breast cancer. Cancer Res 1983, 43:2985-2990.

45. Osborne CK, Schiff R: Mechanisms of endocrine resistance in breast cancer. Annu Rev Med 2011, 62:233-247.

46. Rugo HS: The breast cancer continuum in hormone-receptor-positive breast cancer in postmenopausal women: evolving management options focusing on aromatase inhibitors. Ann Oncol 2008, 19:16-27.

47. Kurebayashi J: Resistance to endocrine therapy in breast cancer. Cancer Chemother Pharmacol 2005, 56:39-46.

48. Lappano R, Maggiolini M: G protein-coupled receptors: novel targets for drug discovery in cancer. Nat Rev Drug Discov 2011, 10:47-60.

49. El Zein N, D'Hondt S, Sariban E: Crosstalks between the receptors tyrosine kinase EGFR and TrkA and the GPCR, FPR, in human monocytes are essential for receptors-mediated cell activation. Cell Signal 2010, 22:1437-1447.

50. Migliaccio A, Di Domenico M, Castoria G, de Falco A, Bontempo P, Nola E, Auricchio F: Tyrosine kinase/p21ras/MAP-kinase pathway activation by estradiol-receptor complex in MCF-7 cells. EMBO J 1996, 15:1292-1300.

51. Castoria G, Migliaccio A, Bilancio A, Di Domenico M, de Falco A, Lombardi M, Fiorentino R, Varricchio L, Barone MV, Auricchio F: PI3-kinase in concert with Src promotes the S-phase entry of oestradiol-stimulated MCF-7 cells. EMBO J 2001, 20:6050-6059.

52. Castoria G, Migliaccio A, Di Domenico M, Lombardi M, de Falco A, Varricchio L, Bilancio A, Barone MV, Auricchio F: Role of atypical protein kinase $C$ in estradiol-triggered G1/S progression of MCF-7 cells. Mol Cell Biol 2004, 24:7643-7653.

53. Migliaccio A, Di Domenico M, Castoria G, Nanayakkara M, Lombardi M, de Falco A, Bilancio A, Varricchio L, Ciociola A, Auricchio F: Steroid receptor regulation of epidermal growth factor signaling through Src in breast and prostate cancer cells: steroid antagonist action. Cancer Res 2005, 65:10585-10593.

54. Levin ER: Bidirectional signaling between the estrogen receptor and the epidermal growth factor receptor. Mol Endocrinol 2003, 17:309-317.

55. Migliaccio A, Castoria G, Di Domenico M, Ciociola A, Lombardi M, De Falco A, Nanayakkara M, Bottero D, De Stasio R, Varricchio L, Auricchio F: Crosstalk between EGFR and extranuclear steroid receptors. Ann N Y Acad Sci 2006, 1089:194-200.

56. Migliaccio A, Castoria G, Auricchio F: Src-dependent signalling pathway regulation by sex-steroid hormones: therapeutic implications. Int J Biochem Cell Biol 2007, 39:1343-1348.

57. Auricchio F, Migliaccio A, Castoria G: Sex-steroid hormones and EGF signaling in breast and prostate cancer cells: targeting the association of Src with steroid receptors. Steroids 2008, 73:880-884.

58. Levin ER: Plasma membrane estrogen receptors. Trends Endocrinol Metab 2009, 20:477-482.

59. Wetherill YB, Akingbemi BT, Kanno J, McLachlan JA, Nadal A, Sonnenschein C, Watson CS, Zoeller RT, Belcher SM: In vitro molecular mechanisms of bisphenol A action. Reprod Toxicol 2007, 24:178-198.

60. Dong S, Terasaka S, Kiyama R: Bisphenol A induces a rapid activation of Erk1/2 through GPR30 in human breast cancer cells. Environ Pollut 2011 159:212-218.

61. Tennant MK, Hill DS, Eldridge JC, Wetzel LT, Breckenridge CB, Stevens JT: Chloro-s-triazine antagonism of estrogen action: limited interaction with estrogen receptor binding. J Toxicol Environ Health 1994, 43:197-211.

doi:10.1186/bcr3096

Cite this article as: Lappano et al:: MIBE acts as antagonist ligand of both estrogen receptor $\alpha$ and GPER in breast cancer cells. Breast Cancer Research 2012 14:R12 